\title{
CONTRACTOR SELECTION FOR PERFORMANCE-BASED MAINTENANCE PARTNERSHIPS
}

\author{
Ad STRAUB ${ }^{1}$ and Henk-Jan van MOSSEL ${ }^{2}$ \\ 1 OTB Research Institute for Housing, Urban and Mobility Studies, Delft University \\ of Technology, PO Box 5030, 2600 GA Delft, The Netherlands. \\ E-mail: a.straub@tudelft.nl \\ 2 OTB Research Institute for Housing, Urban and Mobility Studies, Delft University \\ of Technology, PO Box 5030, 2600 GA Delft, The Netherlands. \\ E-mail: j.h.vanmossel@tudelft.nl
}

Received 19 December 2006; accepted 23 February 2007

\begin{abstract}
Dutch housing associations use new procurement methods such as performance-based maintenance partnerships for maintaining their housing stock. Such partnerships promise a range of advantages as compared to the traditional tendering of maintenance projects. For contractors a performance-based approach implies major changes in methods and work processes. A major change within this performance-based approach is contractors acting as maintenance-engineering consultants to clients. This requires new activities to be considered, such as providing advice on maintenance strategies, the design of maintenance scenarios, performance measurements and conducting customer satisfaction surveys. The execution of these activities demands additional capabilities from the contractor. The introduction of the Quality Mark for Real Estate Maintenance VGO KEUR is a first step in quality assurance of maintenance contractors in the Netherlands. It guarantees principals that contractors are able to work according performance-based methods and procedures. A next step in quality assurance should be to establish a clear relationship between maintenance-engineering and consulting activities and contractor's performance outcome.
\end{abstract}

KEYWORDS: Contractor selection; Maintenance; Partnering; Performance-based procurement; Quality assurance

\section{INTRODUCTION}

Dutch housing associations are not-forprofit organisations, that are obliged to operate in the interest of housing, by providing the lower income households decent and affordable housing. They account for approximately 99\% of the entire social rented housing stock. In 2004, 508 Dutch housing associations owned more than 2.4 millions of the rented dwellings (Centraal Fonds Volkshuisvesting, 2004). This means that social rented housing sector account for 37 percent of the total housing stock, and 75 percent of the total rented stock.
In the 1990s, the Dutch national government has granted housing associations considerable freedom of policy but at the same time diminished its financial support. Since then the world of housing associations has been engulfed with many mergers. The number of housing associations declined from 824 in 1990 to 701 in 2000 . Concurrently housing associations began to adopt business-like approaches in their housing management. They became more market-driven and client-driven (Gruis and Nieboer, 2004). They chose to re-focus on their core business, and many now regard maintenance as a secondary process for which

International Journal of Strategic Property Management

ISSN 1648-715X print / ISSN 1648-9179 online (C) 2007 Vilnius Gediminas Technical University

http://www.ijspm.vgtu.lt 
outsourcing, provided it is organised responsibly, is preferable.

The professionalism of housing associations has led to a noticeably greater attention towards new maintenance processes and partnership forms in the procurement of maintenance. The growth in the size of the properties for which an individual housing association is responsible was an important factor in considering the adoption of performance-based maintenance contracting. Nowadays some larger associations manage as many as 40,000 dwellings, which makes it essential for them to explore alternatives that enable maintenance processes to be managed more efficiently and effectively.

\subsection{Contractor selection and quality assurance}

Performance-based maintenance partnering is concerned with the dyadic relationships between the housing association and its key maintenance contractors. For performancebased partnerships to be successful, the selection of maintenance contractors is extremely important. Traditionally, the responsibility for procuring maintenance work rested on the staff of a technical department of a housing association, i.e. the maintenance project managers. Partnering involves that the choice of maintenance contractors is made at a key level in the organisation, e.g. a central procurement department.

For housing associations that want to adopt a performance-based approach in the maintenance of their buildings, quality control of contractors' processes is valuable and helps in making a decision of whether to enter into a partnership with a contractor or not. Quality assurance means keeping up the methods and procedures of quality control, i.e. systematically checking that they are efficient, that they lead to the desired objectives, and that they are applied in a correct way (Van Weele, 2002). Quality assurance of maintenance contractors processes, therefore, provides valuable insights into the availability of the resources and capabilities required delivering satisfying maintenance work and high quality consultancy-services to their clients.

\subsection{Research question}

The paper focuses on contractor selection and quality assurance for performance-based maintenance projects and partnerships. It highlights engineering-consultancy services that are delivered to enable design-build combinations in maintenance. In this paper performance-based maintenance is concerned with planned preventive maintenance (i.e. condition-based maintenance) of the building envelope.

The research question is: What resources and capabilities do maintenance contractors need to enable them to act as maintenance-engineering consultants to housing associations in performance-based maintenance partnering, and in what way can housing associations be assured of these resources and capabilities?

A literature study and interviews with directors of maintenance firms as well as purchasers and technical managers of housings associations gave data about the current selection processes of maintenance contractors and the need for maintenance contractors acting as maintenance engineering consultants. Data on quality assurance of maintenance contractors is derived from an extensive literature analysis. The central case is VGO KEUR, which means Quality Mark for Real Estate Maintenance and is a newly developed independent quality mark for maintenance firms (Stichting Certificatie Technisch Vastgoedbeheer, 2005). For a major part the approval system consists of the verification of the competences that are required to execute performance-based maintenance. This paper includes the assessment by the authors of opportunities that the VGO KEUR offers. The quality mark was introduced not until recently. In the future outcome measurements will provide empirical results. 


\section{SELECTION OF MAINTENANCE CONTRACTORS}

Dutch housing associations procure the majority of maintenance projects by selective tendering, i.e. inviting, three to five competitive bids and choosing the lowest one. Direct one-to-one-contracts based on unit prices or full cost reimbursement contracts as well as regular contracts are also often used (Vijverberg, 2004). Because European legislation for public tendering is not mandatory for Dutch housing associations, this type of tendering is rarely used. The actual tender is usually awarded to well-known, pre-selected parties. This process effectively results in two lists of contractors: those on a 'white list' and those on a 'black list'. The contractors are considered blacklisted contractors when they fail to meet the requirements of housing associations.

\subsection{Pre-selection}

In pre-selecting contractors, common selection criteria of Dutch housing associations are related with the technical abilities, the financial position and the integrity of the contractor. References from colleagues and purchasers' own experiences are also used in determining the suitability of suppliers. Innovative clients may also demand capabilities of suppliers on matters such as the innovative ability, the added value in the longer run, environmental aspects, the dependability of the customer for the supplier, and the supplier's position in the supply chain.

Every organisation holds its own independent 'approved list'. In the UK the Government-backed Trustmark was set up, allowing several trades, e.g. painters, to demonstrate a commitment to quality and allowing the users to select quality conscious painters (Suttie and Thorpe, 2003; Trimmer and Kidston, 2003). National pre-qualification systems do not exist in the Netherlands. However, contractors set up a wide range of quality assurance systems.

\subsection{Contractor selection}

Zavadskas and Vilutiene (2006) made an extensive review of techniques for contractor selection used in different countries. They conclude that there are only a few studies in which the selection process of maintenance contractors is analysed. The selection of construction contractors is based on a number of criteria associated with the contractors' characteristics, such as financial position, past experiences and tender prices. Zavadskas and Vilutiene (2006) argue that maintenance and construction are processes of different natures: "In a maintenance field, clients are concerned not only with the final result, but with the maintenance process as well. Therefore a set of selection criteria for maintenance work would be substantially different from that of construction work". Clients, which are tenants, are particularly concerned with daily maintenance. In planned preventive maintenance the efficient performance of contractors is crucial, sustaining the value of the assets and acquiring tenants' satisfaction. In performance-based maintenance partnerships, contractors have the responsibility for performance and customer satisfaction during the entire contract period.

\section{QUALITY ASSURANCE OF MAINTENANCE CONTRACTORS}

The Dutch construction and maintenance industry is characterised by many small firms and some large companies and by heterogeneity in the types of firms (Bremer and Kok, 2000). The degree of specialisation varies considerably. A lot of (small) maintenance companies has specialised in only one kind of work, for example paintwork. Another group of companies combines expertise from various fields and exercise 'total maintenance'. The firms that has specialised in paintwork and small construction work can be divided into two groups: a large group of very small firms (1-10 employees) and a small group of medium-sized firms (up to 150 employees). All members of 
the association of medium-sized employers, the WVB, have adopted the 'Excellence model' as provided by the European Foundation for Quality Management (EFQM) as their generic management quality system. Some firms are assessed for ISO 9000 series and/or ISO 14001 (environmental management systems).

In 1995, the branch organization of painting firms introduced an approval system for painting firms, the 'AF-erkenningsregeling'. The firms need certificates of proficiency to become certified/approved. Quality control of the maintenance service is done by means of a performance measurement of a painting job every three years. For non-professional clients this approval is important, because the quality of painting work is guaranteed for two years. Besides, the firms observe the consumer terms of the Dutch consumers' organization. For professional clients like housing associations, it is essential that the contractors working for them have implemented the voluntary quality assurance system referred to as the Safety, Health and Sustainability Checklist: VCA. This VCA applies for small firms that have less than 35 employees (VCA*), usually working as a subcontractor, and in a more comprehensive version also for larger firms $\left(\mathrm{VCA}^{* *}\right)$. VCA* includes the direct safety control of working processes at site. VCA** further includes the management and organisation of the firm. Requirements are interrelated with requirements of ISO 9001 (Federatie van
Afbouw Bedrijfsschappen, 2002). VCA-certification of contractors is used very often as a prequalification criterion of clients in the Dutch construction industry (Caniels, 2005). The integrity of building companies has become an important issue after inquiries of collusion practices in the Dutch building industry (Dorée, 2004). For this reason, building contractors can be registered as integer companies, observing the codes of the Corporation for the Assessment of Integrity of the Construction Industry (Stichting Beoordeling Integriteit Bouwnijverheid, 2003).

The maintenance contractors can also become certified for several working processes and technical skills, according to Dutch and/or international standards. Some members of the WVB, for example, are certified/approved contractors for various techniques for concrete repair and/or approved contractors for maintenance of exterior woodwork. The workmanship of workers who in fact execute the job is quite important for quality of the maintenance work. That is why workers may also get themselves approved or certified. Generally, knowledge and experience of workers is part of the quality management system and/or the process quality system of certified/approved firms.

Table 1 shows different types of quality systems for Dutch maintenance contractors specialized in planned preventive maintenance of the building envelope.

Table 1. Quality systems for Dutch maintenance contractors

\begin{tabular}{llll}
\hline & General & Aspects & Activities \\
\hline $\begin{array}{l}\text { Management and } \\
\text { organisation }\end{array}$ & ISO 9000 series & SBIB & $\begin{array}{l}\text { Approval system for painting firms (AF- } \\
\text { erkenningsregeling) } \\
\text { EFQM }\end{array}$ \\
$\begin{array}{ll}\text { Working processes at } \\
\text { building site }\end{array}$ & VCA* & $\begin{array}{l}\text { Approval system for roofers (Dakmerk) } \\
\text { Concrete repair Standard }\end{array}$ \\
& & Woodwork maintenance Standard \\
Workmen skills & & Dakmerk \\
& & Concrete repair Standard \\
& & Woodwork maintenance Standard \\
& & Approval system for painting firms (AF- \\
& & erkenningsregeling) \\
& & Approval system for roofers (Dakmerk) \\
\hline
\end{tabular}




\section{PERFORMANCE-BASED MAINTENANCE PROCUREMENT AND MAINTENANCE ENGINEERING CONSULTANCY}

Traditionally, housing associations tendering maintenance services use a descriptive and detailed specification of the work to be performed. The objectives are to achieve the lowest price or the best price-quality ratio by means of a competitive tender. The specifications are drawn up using the available knowledge and experiences of the housing association, possibly with assistance from external maintenance advisors. By contrast, the performance-based approach is based on a set of desired performances or service levels, set down by the housing association.

Generally, the objectives of housing associations for performance-based maintenance partnering are:

- achieving budget certainty and cost savings,

- improving product quality,

- simplifying the maintenance management process,

- and, promoting innovation by maintenance contractors.

The performance-based approach means that maintenance contractors no longer act as suppliers of maintenance work capacity, but as active participants in the overall maintenance process. They give advice on maintenance strategies, maintenance scenarios, performance specifications and activities (Straub, 2005). In other words, they start to act as engineering-consultants.

In a previous research project, conducted for seven housing associations and the Dutch Building Research Foundation (SBR), partnership forms for condition-based maintenance services have been developed (Straub et al., 2005). Figure 1 illustrates the process model of long-term co-operation. Together with the client the contractor specifies decisive performance requirements and determines the starting point for the maintenance process and maintenance planning. Other consultancy activities conducted by maintenance contractors for housing associations are shown in shaded boxes in Figure 1, which are executing condition assessments, the design of maintenance scenarios and activity plans and executing periodic performance measurements.

\subsection{Design of maintenance scenarios and specifying maintenance activities}

In performance-based maintenance partnerships, contractors act as maintenance-engineering consultants. The contractors are selected at an early stage and this enable them to contribute to ideas about maintenance strategies within the constraints of performance requirements, the exploitation period, and the financial aspects that apply to each housing complex. The housing association and the maintenance contractor jointly specify decisive performance requirements for housing estates, which is concluded in a general agreement. In this model the key issue is re-design of the relevant building components. Re-design is an integral part of the specification phase. The technical solutions are set down in maintenance scenarios and activity plans, presenting net present values of life cycle costs and performance criteria. A partnership agreement is then concluded that covers a maintenance scenario consisting of several maintenance intervals that may last for the entire exploitation period of the housing estate. The first activity plan is set down in a performance agreement.

\subsection{Performing performance measurements and conducting customers' satisfaction surveys}

The contractors themselves monitor the deterioration processes of building components by performing performance measurements. The main purpose of control and supervision by the housing association is to review the performance achievements and to identify problems and subsequently, take the necessary ac- 


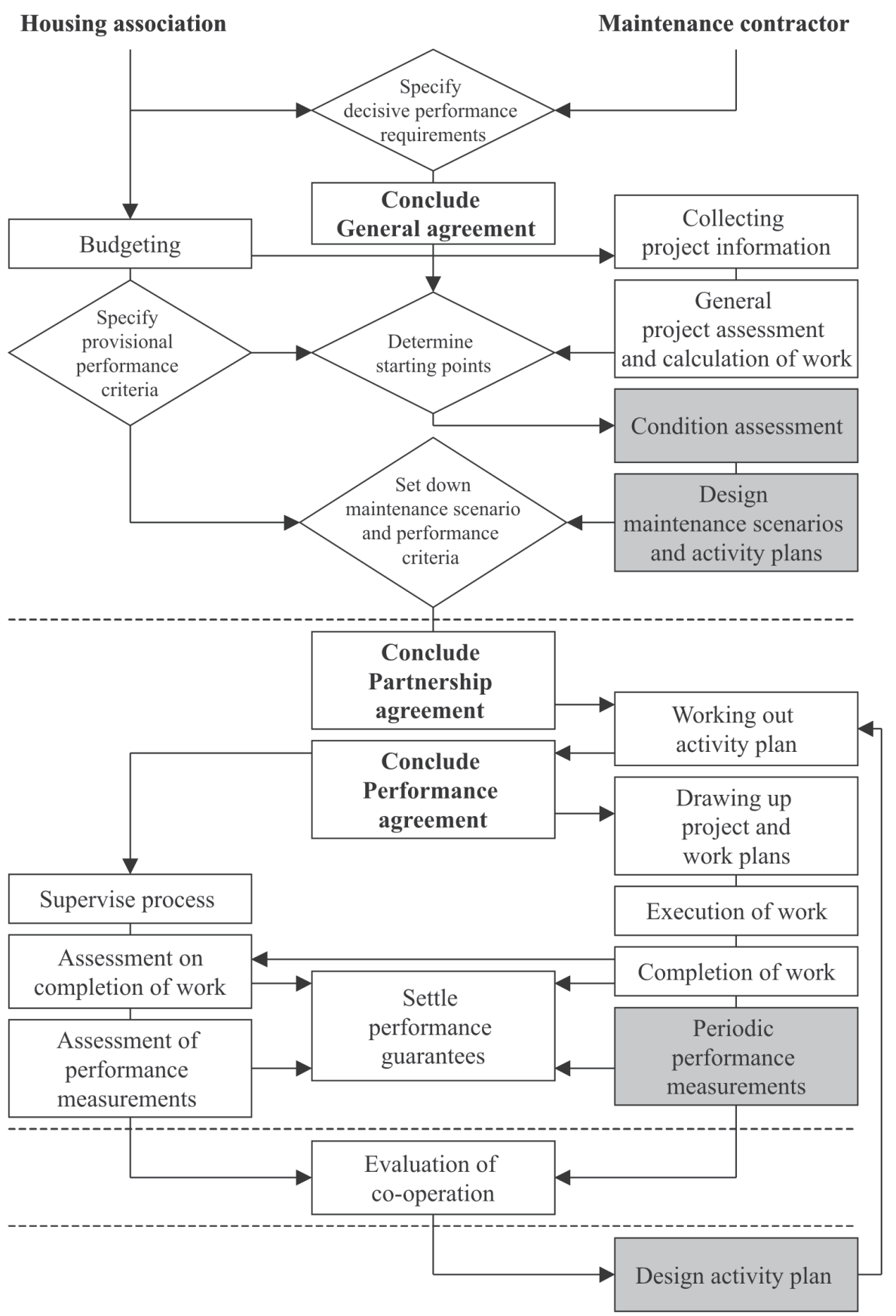

Figure 1. Flowchart process model of long-term co-operation (Straub et al., 2005; revised) 
tion. Contractors also monitor the entire maintenance process and especially customer satisfaction, during maintenance interventions. They are responsible for laid down performances and customers satisfaction during the contract period.

\section{SELECTION OF MAINTENANCE CONTRACTORS FOR PERFORMANCE- BASED MAINTENANCE PARTNERSHIPS}

Within performance-based partnerships, the selection of maintenance contractors with whom the client wishes to work is very important. Performance-based maintenance partnerships influence the internal organisation of the client and contractors and the selection of contractors. Parties to the relationship should have similar views and approach the partnership arrangement with similar perspectives. Partnering literature, e.g. Bresnen and Marshall (2000), Saad et al., (2002), emphasises the need for a thorough understanding of such a new concept as partnering, and the ability to create, manage, and reshape relationships. Also, it is essential that contractors are motivated to increase performance (Kashiwagi and Byfield, 2002).

\subsection{Needed competences maintenance contractors}

For contractors a performance-based approach means major changes in working processes, methods, and the need for information. Several authors examined which competences are required of contractors working as consultants in design-build projects, especially in the area of contractor selection (e.g. Potter and Sanvido, 1995; Palaneeswaran and Kumuraswamy, 2000).

The core competence of maintenance-engineering consultants should be their ability to apply scientific and technical knowledge (in a combined form of technical calculations and tacit knowledge of design, based on extensive experience) to a maintenance project. To exploit this core competence, the consultant, however, is dependent on resources and capabilities. Barney (1991) categorized resources into three groups: physical resources such as plant equipment, location and assets; human resources such as manpower, management team, training and experience; and organizational resources such as culture and reputation. Capabilities are defined as "architectural abilities or bonding mechanisms whereby resources are combined in new and innovative ways" (Duncan et al., 1998).

The required capabilities of maintenanceengineering consultants can be compared to those required by management consultants. Simon and Kumar (2001) have conducted studies to the strategic capabilities of management consultants, as identified by clients. Although the strategic capabilities of management consultants do not necessary reflect those required by performance-based maintenance consultant, it could be assumed that they bear many similarities. The importance of communication and empathy skills towards the client is obvious for all consultancy activities. For engineering consultancy, the quality of the result of the service will dependent heavily on the technical knowledge. Together with the integrity and honesty of the consultant, these seem to be the most important strategic capabilities from the viewpoint of the client.

The resources of engineering consultants rest firmly on the skills accumulated by their professionals as individuals and in project groups. For example, it can be argued that every new design or construction project involves innovative elements such as the adaptation of existing technology to local conditions, or unique combinations of technical components. Of particular interest for maintenanceengineering consultancy, is knowledge of and experience with condition assessment and performance measurement, methods for diagnosing the cause of deterioration, planning and calculation methods (e.g. net present values, life-cycle costing), and knowledge of the life 
span of building components. Contractors should substantiate the (financial) risks associated with the various maintenance scenarios. For example, the contractors must be able to assess whether damage is likely to reoccur or whether damage to other parts of the exterior envelope will increase, given certain maintenance work. In co-operation with manufacturers, e.g. for coatings and roofing systems, they have to guarantee clients the service life of (new) materials and construction elements.

To a large extent, the real competitive assets of engineering consultants are thus contingent on their human resources (Baark, 2001). In addition to this, the quality of memorization of knowledge within the organisation affects the sustainability of these resources. Concurrently, as the consultant in performance-based projects and partnerships is part of the maintenance firm, the most important capability of this firm lies in combining resources and the degree it succeeds in obtaining synergy by combining design and execution of maintenance work.

\section{VGO KEUR: QUALITY MARK FOR REAL ESTATE MAINTENANCE}

The WVB, the SBR and the approved scheme operator INTRON Certificatie have been working on a system of quality assurance. Major part of this approval system is a verification of performance-based competences of maintenance companies. It is primarily directed to maintenance, and in particular paintwork of the building envelope. In the near future an independent institution including members from the contractor side as well as the principal side, will manage this system. Then all maintenance contractors can be certified as contractors that are able to work according to performance-based maintenance methods and procedures.

Maintenance contractors start the application procedure regarding the VGO KEUR with submitting the application form. After a superficial check on requirements, an in-depth assessment is undertaken. If the maintenance contractor succeeds in meeting the requirements, it is granted the quality mark VGO KEUR. See Figure 2.

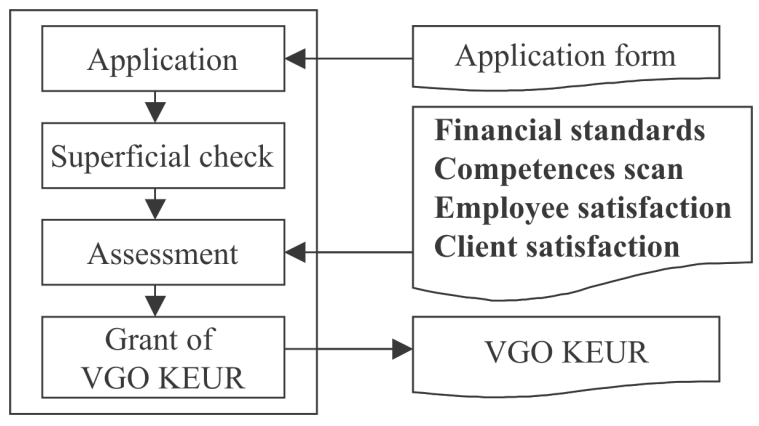

Figure 2. Application process for VGO KEUR

VGO KEUR includes a wide range of requirements: financial standards, competences and contractors' performance outcomes. Financial performance standards contain net profit and solvency figures from the past. Contractors' performance outcome is assessed by employee and client satisfaction. Employee satisfaction is measured using the indicator 'absence through illness'. The requirements are assessed each year. Client satisfaction is measured through an inquiry among randomly selected clients of the contractor. The principals have to indicate their satisfaction with the contractor on a ten point-scale. The average total score should be at least seven, in order to obtain the quality mark. This procedure is repeated every three years.

For the assessment of performance-based competences an extensive questionnaire has been developed. See Table 2. Based on this questionnaire, the contractor's knowledge, expertise and experience with maintenance processes and consultancy activities are assessed every three years. A typical question that is included is: "To what extent is the contractor capable of developing maintenance scenarios?" For most of the questions the proof is provided by written documents, such as personnel files and project files 
Table 2. Questions and proof Competences scan VGO KEUR (examples)

\begin{tabular}{|c|c|c|}
\hline & Questions Context & Proof \\
\hline \multirow[t]{3}{*}{ Firm } & $\begin{array}{l}\text { Financial turnover of current long-term } \\
\text { relationships }\end{array}$ & Financial statements \\
\hline & Disciplines of available in-house employees & Files personnel \\
\hline & Relationships with subcontractors & Financial statements \\
\hline \multirow[t]{2}{*}{$\begin{array}{l}\text { Leadership and } \\
\text { management }\end{array}$} & $\begin{array}{l}\text { Knowledge of and experience in business } \\
\text { administration, financial management, risks } \\
\text { management }\end{array}$ & Certificates, diplomas \\
\hline & $\begin{array}{l}\text { Information supply to employees about company } \\
\text { strategy, including the performance-based } \\
\text { approach }\end{array}$ & Minutes meetings, inquiry personnel \\
\hline \multirow[t]{3}{*}{$\begin{array}{l}\text { Performance-based } \\
\text { maintenance process }\end{array}$} & $\begin{array}{l}\text { Knowledge of and experiences in condition } \\
\text { assessments, performance measurements }\end{array}$ & $\begin{array}{l}\text { Certificates, diplomas, personnel files, } \\
\text { project files }\end{array}$ \\
\hline & $\begin{array}{l}\text { Knowledge of and experiences in drawing up } \\
\text { maintenance scenarios and activity plans }\end{array}$ & $\begin{array}{l}\text { Certificates, diplomas, personnel files, } \\
\text { project files }\end{array}$ \\
\hline & $\begin{array}{l}\text { Knowledge of and experiences in planning and } \\
\text { calculation methods }\end{array}$ & $\begin{array}{l}\text { Certificates, diplomas, personnel files, } \\
\text { project files }\end{array}$ \\
\hline Realisation & Knowledge of and experiences in process control & $\begin{array}{l}\text { Certificates, diplomas, personnel files, } \\
\text { project files }\end{array}$ \\
\hline After care & Analysis of performance measurements & $\begin{array}{l}\text { Project files, minutes work } \\
\text { consultations }\end{array}$ \\
\hline
\end{tabular}

of the firm. Generally, a well-documented process demonstrates the competences. Most of the questions are related to the human resources and past experiences. Just a few questions deal with the management and organization of the firm and the management and organization of performance-based partnering. Questions about innovative solutions, contractor's viewpoints on maintenance strategies, management of subcontractors, communication with the client, communication with employees of the client at site and communication with tenants are lacking. Questions about knowledge dissemination are also lacking.

\section{CONCLUSIONS}

Within performance-based partnerships, the selection of maintenance contractors is very important for the client. Parties getting in the relationship should have similar views and should approach the partnership with similar perspectives. Indeed, maintenance contractors develop quality management systems with similar assumptions as housing associations. All members of the association of medium-sized employers WVB have adopted the EFQM Excellence Model. In addition to this, many quality assurance systems exist for overall management processes and technical processes of maintenance contractors. However, the fact that the contractor has to act as a maintenance-engineering consultant to the client is vital for a performance-based maintenance approach. The consultancy activities conducted by maintenance contractors for housing associations include: providing advice on maintenance strategies and design of maintenance scenarios, specifying maintenance activities, executing periodic performance measurements and conducting customer (tenant) satisfaction surveys.

The introduction of the quality mark VGO KEUR in the Netherlands is a first step in quality assurance of maintenance contractors. It guarantees principals that contractors are able to work according performance-based methods and procedures. VGO KEUR includes 
a wide range of requirements: financial standards, competences and contractors' performance outcome.

Financial standards are important aspects in contractor selection, but most principals, housing associations in particular, have their own more extensive selection criteria to cover the financial strength of a contractor. The competences scan should measure performance-based maintenance competences of contractors. Just a well-documented process demonstrates the performance-based competences. Moreover the competences scan primarily measures resources. Conversely, client satisfaction in maintenance-engineering consultancy is heavily determined by capabilities, like communication and empathy skills. Together with the integrity of the consultant, these seem to be the most important strategic capabilities of consultants from the viewpoint of the client. The key question is how to measure these capabilities?

Client satisfaction is determined by contractors' performance outcomes. The relationship between maintenance-engineering and consulting activities and contractors' performance outcomes is not made very clear in the VGO KEUR. Contractors' performance outcomes areassessed by employee and client satisfaction. Linking a quality assurance system for performance-based maintenance to performance outcome requires output measurements of products and services, too. Output measurements might be the technical performance of the maintained building components, contractors' prices during the co-operation period and tenant satisfaction.

VGO KEUR was introduced not until recently. In the future outcome measurements between principals that require the VGO KEUR by maintenance contractors if working in a performance-based partnership and principals that do not require the VGO KEUR will provide the authors empirical results about the relationships between the VGO KEUR, contractors' performance outcome and client satisfaction.

\section{REFERENCES}

Baark, E. (2001) Routines and Innovation in Engineering Consultancy Services, Proceedings of DRUID's Nelson-Winter Conference, Danish Research Unit for Industrial Dynamics, Denmark.

Barney, J. B. (1991) Firm resources and sustained competitive advantage. Journal of Management, 17(1), p. 99-120.

Bremer, W. and Kok, K. (2000) The Dutch construction industry: a combination of competition and corporatism. Building Research and Information, 28(2), p. 98-108.

Bresnen, M. and Marshall, N. (2000) Partnering in construction: A critical review of issues, problems and dilemmas. Construction Management and Economics, 18 (2), p. 229-237.

Caniels, M. E. (2005) Importance of VCA strongly increased. Bouw/Werk, 3, p. 23-24. (In Dutch)

Centraal Fonds Volkshuisvesting (CFV) (2005) Financial Inspection Housing Associations Report 2005, Naarden: CFV. (In Dutch)

Dorée, A. (2004) Collusion in the Dutch construction industry: an industrial organization perspective. Building Research and Information, 32(2), p. 146-156.

Duncan, W. J., Ginter, P. M. and Swayne, L. E. (1998) Competitive Advantage and internal organizational assessment. Academy of Management Executive, 12(3), p. 6-16.

Federatie van Afbouw Bedrijfsschappen (2002) Implementation of the NEN-EN-ISO 9001, the VGM Checklist Contractors VCA and the NENEN ISO 14001 by painting firms, Rijswijk. (In Dutch)

Gruis, V. and Nieboer, N. (eds.) (2004) Asset Management in the Social Rented Sector, Policy and Practise in Europe and Australia, Dordrecht: Kluwer Academic Publishers.

Kashiwagi, D. and Byfield, R. E. (2002) Selecting the best contractor to get performance: On time, on budget, meeting quality expectations. Journal of Facilities Management, 1(2), p. 103-116.

Palaneeswaran, E. and Kumaraswamy, M. M. (2000) Contractor selection for Design/Build Projects. Journal of Construction Engineering and Management-ASCE, 126(5), p. 331-339.

Potter, K. J. and Sanvido, V. (1995) Implementing a Design/Build Prequalification System. Journal of Management in Engineering, 11(3), p. 30-34. 
Saad, M., Jones, M. and James, P. (2002) A review of the progress towards the adoption of supply chain management (SCM) relationships in construction. European Journal of Purchasing and Supply Management, 8(3), p. 173-183.

Simon, A. and Kumar, V. (2001) Clients' views on strategic capabilities which lead to management consulting success. Management Decision, 35(5), p. 362-372.

Stichting AF-Erkenningsregeling (2004) Brochure $A F$-approved skilled worker, Gouda: Stichting AF-Erkeningsregeling. (In Dutch)

Stichting Beoordeling Integriteit Bouwnijverheid (SBIB) (2003) Model Firm Code SBIB, Gouda: SBIB. (In Dutch)

Stichting Certificatie Technisch Vastgoedbeheer (SCTV) (2005) Approval scheme Quality Mark for Real Estate Maintenance (VGO-Keur), Rotterdam: SCTV. (In Dutch)

Straub, A. (2002) Strategic Technical management of housing stock: lessons from Dutch housing associations. Building Research and Information, 30(5), p. 372-381.

Straub, A. (2005) Performance-based partnership forms for maintenance by Dutch housing associations, in Sullivan, K. and Kashiwagi, D. T. (Eds.), Proceedings of the international conference CIB W092 Procurement Systems, The impact of Cultural Differences and Systems on Construction Performance, Las Vegas, p. 459-468.

Straub, A., Vijverberg, G. A. M. and Van Mossel, J. H. (2005) Performance-based co-operation in maintenance, Basis information construction maintenance, Rotterdam: SBR. (In Dutch)

Suttie, E. and Thorpe, W. (2003) Planned maintenance painting: improving value for money, Watford: BRE.

Trimmer, G. and Kidston, N. (2003) Assessing Procurement, London: Trimmer CS and The Housing Corporation.

Van Weele, J. (2002) Purchasing and supply chain management, Analysis, Planning and Practise, London: Thomson Learning.

Vijverberg, G. (2004) Strategic housing stock policy and maintenance management practise in Dutch social housing, in Then, D. S. S., Jones, K., and Hinks, J. (eds.), Proceedings of the international conference CIB W070 Facilities Management and Maintenance, Human elements in Facilities Management - Understanding the Needs for Our Customers, Hong Kong, p. 337-346.

Zavadskas, E. K. and Vilutiene, T. (2006) A multiple criteria evaluation of multi-family apartment block's maintenance contractors: I-Model for maintenance contractor evaluation and the determination of its selection criteria. Building and Environment, 41(5), p. 621-632. 


\section{SANTRAUKA}

RANGOVO PARINKIMAS EKSPLOATACIJA GRİSTŲ PASTATŲ PRIEŽIŪROS PARTNERYSTEI Ad STRAUB, Henk-Jan van MOSSEL

Vykdydamos pastatų ūkio priežiūrą, Olandijos būsto asociacijos taiko naujus pirkimo metodus, tokius kaip eksploatacija grịstų pastatų priežiūros partnerystė. Tokia partnerystė turi daug pranašumų, palyginti su tradiciniais priežiūros projektų konkursais. Rangovams eksploatacija grịstų pastatų priežiūros būdas reiškia reikšmingus metodų ir darbo proceso pokyčius. Esminis su eksploatacija grịstų pastatų priežiūros būdu susijęs pokytis - rangovai klientams teikia priežiūros ir konsultavimo dèl inžinerinių sistemų paslaugas. Todẻl reikia pasidomėti nauja veikla, tokia kaip konsultacijos dèl priežiūros strategijų, priežiūros scenarijų rengimas, naudingumo matavimai ir klientų pasitenkinimo apklausų rengimas. Kad galètų vykdyti tokią veiklą, rangovas turi turèti papildomų gebẻjimų. Nekilnojamojo turto priežiūros kokybès ženklo VGO KEUR naudojimas - pirmasis žingsnis siekiant Nyderlanduose užtikrinti pastatų ūkio priežiūros rangovų veiklos kokybę. Užsakovams tai garantuoja, kad rangovai sugebės vykdyti veiklą, remdamiesi rezultatyviaisiais metodais ir procedūromis. Kitas žingsnis, siekiant užtikrinti kokybę, turètų būti aiškaus ryšio tarp priežiūros, inžinerinès ir konsultavimo veiklos bei rangovo rezultatų nustatymas. 